KAPL-P-000045

(K96041)

CONF- $9605 / 3--$

\title{
PRODUCTION DATA ON 0.55 EV INGAAS THERMOPHOTOVOLTAIC CELLS
}

S. Wojtczuk, P. Colter, G. Charache, B. Campbell

May1996

\section{NOTICE}

This report was prepared as an account of work sponsored by the United States Government. Neither the United States, nor the United States Department of Energy, nor any of their employees, nor any of their contractors, subcontractors, or their employees, makes any warranty, express or implied, or assumes any legal liability or responsibility for the accuracy, completeness or usefulness of any information, apparatus, product or process disclosed, or represents that its use would not infringe privately owned rights.

Operated for the U. S. Department of Energy by KAPL, Inc. a Lockheed Martin company 


\section{DISCLAIMER}

This report was prepared as an account of work sponsored by an agency of the United States Government. Neither the United States Government nor any agency thereof, nor any of their employees, makes any warranty, express or implied, or assumes any legal liability or responsibility for the accuracy, completeness, or usefulness of any information, apparatus, product, or process disclosed, or represents that its use would not infringe privately owned rights. Reference herein to any specific commercial product, process, or service by trade name, trademark, manufacturer, or otherwise does not necessarily constitute or imply its endorsement, recommendation, or favoring by the United States Government or any agency thereof. The views and opinions of authors expressed herein do not necessarily state or reflect those of the United States Government or any agency thereof. 


\section{DISCLAIMER}

Portions of this document may be illegible in electronic image products. Images are produced from the best available original document. 


\title{
PRODUCTION DATA ON $0.55 \mathrm{eV}$ InGaAS THERMOPHOTOVOLTAIC CELLS
}

\author{
S. Wojtczuk and P. Colter, Spire Corporation, Bedford, MA 01730 USA
}

G. Charache and B. Campbell, Lockheed Martin, Inc., Schenectady, NY 12301 USA

\begin{abstract}
Low bandgap $0.55 \mathrm{eV}$ ( $2.25 \mu \mathrm{m}$ cutoff wavelength) indium gallium arsenide $\left(\mathrm{In}_{0.72} \mathrm{Ga}_{0.28} \mathrm{As}\right)$ thermophotovoltaic (TPV) cells use much more of the long wavelength energy emitted from low temperature $\left(<1200^{\circ} \mathrm{C}\right)$ thermal sources than either Si or GaSb cells. Data are presented on a statistically significant number $(2500)$ of these TPV cells, indicating the performance obtainable in large numbers of cells. This data should be useful in the design and modeling of TPV system performance. At $1.2 \mathrm{~A} \mathrm{~cm}^{2}$ short-circuit current, an average open-circuit voltage of $283 \mathrm{mV}$ is obtained with a $60 \%$ fill factor. The peak external quantum efficiency for uncoated cells is $65 \%$ and is over $50 \%$ from 1.1 to $2.2 \mu \mathrm{m}$. Internal quantum efficiency is over $76 \%$ in this range assuming an estimated $34 \%$ reflectance loss.
\end{abstract}

\section{OVERVIEW}

The main components of a thermophotovoltaic power system include a heat source (which normally has a broad blackbody spectrum, but may also be a selective emitter), photovoltaic cells, and (in cases where the emitter is not selective) an optical filter to reflect photons with energy below the cell bandgap back to the heat source to help maintain its temperature.

This paper describes production data on a certain type (0.55 $\mathrm{eV}$ InGaAs) of photovoltaic cell, one of the main components of the TPV system. In this section, we very briefly describe how the heat source temperature and optical filter relate to the cell, and discuss the relative benefits of several cell types ( $\mathrm{Si}, \mathrm{GaSb}$, InGaAs) now in use with TPV systems. Our goal in this section is to outline why $0.55 \mathrm{eV}$ inGaAs cells may be the best choice for TPV system applications where the heat source is $-1200^{\circ} \mathrm{C}$ or below.

High temperature sources $\left(>2300^{\circ} \mathrm{C}\right)$ would allow use of relatively inexpensive, standard Si photovoltaic cells. However, self-contained, high temperature sources are harder to build due to the scarcity of materials which can withstand high temperatures. Therefore, lower temperature sources are being considered for applications such as the $-1100^{\circ} \mathrm{C}$ radioisotope General Purpose Heat Source [1] for deep space missions, $-1220^{\circ} \mathrm{C}$ solar thermophotovoltaics [2] with energy storage for commercial power grid use, and small $-1250^{\circ} \mathrm{C}$ natural gas TPV generators [3] for home use.
All of these applications require a low bandgap cell, since the spectral peak of a $1200^{\circ} \mathrm{C}$ blackbody falls at $2 \mu \mathrm{m}$ (see Fig. 1). Only $2 \%$ of the total $1200^{\circ} \mathrm{C}$ blackbody energy is from photons with energy above the $1.1 \mathrm{eV}$ bandgap of a Si cell, versus $15 \%$ for $0.72 \mathrm{eV} \mathrm{GaSb}$ and $35 \%$ for $0.55 \mathrm{eV}$ InGaAs cells. Efficient cells with even lower bandgaps are desired, but are unlikely to be available anytime soon.

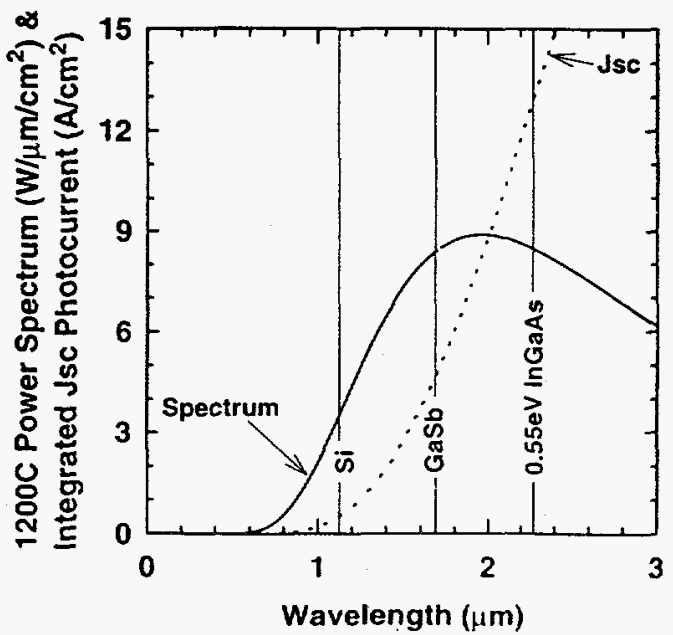

Fig. 1 Power spectral density in $W / \mu \mathrm{m} / \mathrm{cm}^{2}$ and integrated short circuit photocurrent (Jsc) in $\mathrm{Acm}^{2}$ for a $1200^{\circ} \mathrm{C}$ blackbody. Calculated Jsc assumes $100 \%$ quantum efficiency for all cell types out to the cutoff wavelength. Horizontal lines mark cutoffs of $1.1 \mathrm{eV}$ Si, $0.72 \mathrm{eV} \mathrm{GaSb}$, and $0.55 \mathrm{eV}$ inGaAs.

Figure 1 shows that the lower bandgap $2.25 \mu \mathrm{m}$ cutoff $0.55 \mathrm{eV}$ InGaAs cells potentially could have $-3 \mathrm{X}$ higher Jsc than $1.7 \mu \mathrm{m}$ cutoff GaSb cells (12.5 vs $\left.4.5 \mathrm{~A} / \mathrm{cm}^{2}\right)$. However, higher bandgap $0.72 \mathrm{eV}$ GaSb cells can have more photovoltage ( $500 \mathrm{mV}$, Voc of best cell in [3]) than the $0.55 \mathrm{eV}$ InGaAs ( $307 \mathrm{mV}$, best cell reported here) and GaSb has a higher fill factor ( $80 \%$ vs $67 \%$ for best cells in [3] versus those reported here) as well. Overall however, using the above data, about $43 \%$ more power per area could be available from the $0.55 \mathrm{eV}$ InGaAs cells than from $0.72 \mathrm{eV}$ GaSb cells under a $1200^{\circ} \mathrm{C}$ blackbody source. 


\section{QUANTUM EFFICIENCY}

The 50X AMO short wavelength data in Table 2 is basically useful for predicting the photovoltage and fill factor of these cells in a TPV system given a certain photocurrent. However, in order to predict the photocurrent in a TPV application, a system designer would need to know both the TPV cell quantum efficiency (QE) as a function of wavelength and the power spectral density from whatever TPV heat source is planned for use. The external QE for a typical $0.55 \mathrm{eV}$ InGaAs TPV cell is shown in Figure 2. The external QE is above 50\% from about 1 to $2.1 \mu \mathrm{m}$.

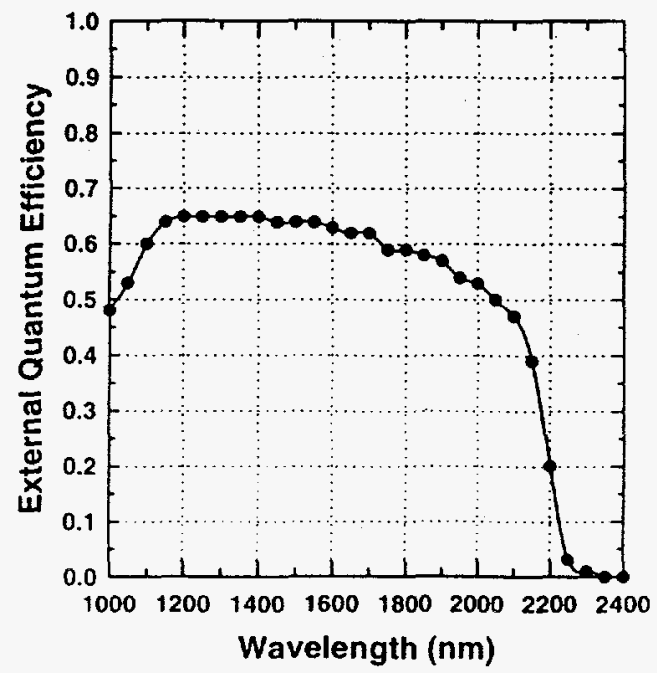

Fig. 2 Measured extemal quantum efficiency for $0.55 \mathrm{eV}$ InGaAs cell without any antireflection coating.

The internal QE is of interest as a measure of the intrinsic cell response, and is simply a correction to the external quantum efficiency to account for the reflectance from the cell surface. We will assume the $0.55 \mathrm{eV}$ InGaAs refractive index $(\sim 3.5)$ is fairly flat with wavelength, so that the normal incidence reflectance in air is estimated as $31 \%$. in addition, the $10 \%$ gridline coverage on the cell surface would increase this by $3 \%$ to $34 \%$. The peak internal QE is then $98 \%$ (vs $65 \%$ external), with the internal QE above $76 \%$ from 1 to $2.1 \mu \mathrm{m}$.

\section{CORRELATION OF VOC AND X-RAY FWHM}

The exact indium (In) composition percentage $(x)$ of the $\ln _{x} \mathrm{Ga}_{1-x}$ As cell layers is of great interest since this determines the bandgap energy and cutoff wavelength of the ternary InGaAs material. To determine this quantity, first the material lattice constant is measured with a doublecrystal X-ray diffractometer.
Once the lattice constant is known from the position of the X-ray diffractometry peak with respect to the wellknown InP water peak, a unique composition can be ascribed to the $\ln _{x} \mathrm{Ga}_{1 . \times}$ As material. The target for this work is the $0.55 \mathrm{eV} \ln _{0.72} \mathrm{Ga}_{0.28}$ As composition. The full-widthhalf-maximum (FWHM) of this X-ray diffraction peak is popularly considered an indicator of the material quality (broader peaks normally indicate less perfect material).

Table 2 lists the average FWHM of about 200 MOCVD growth runs on both three and two-inch inP wafers. Likewise, the cell open-circuit voltage Voc is fairly sensitive to the dark current, which in turn is sensitive to the material quality (e.g. the number of dislocation defects). It would be a great advantage if the FWHM of the X-ray diffraction peak, which is measured after epitaxial growth but before any material processing, could be used to accurately predict the Voc, a critical cell parameter. This would allow us to eliminate "bad" wafers and process only good wafers, for an appreciable cost saving.

Unfortunately, Figure 3 shows the correlation (or more accurately, the lack of correlation) between the FWHM of the X-ray peak and the Voc. As of the present time, we still do not know for certain why there is so little correlation. We suspect that on many samples the $1 \mathrm{~cm}$ wide X-ray "footprint" may cut across several inGaAs regions that, although of the same composition, may have slightly different growth tilts, widening the perceived $X$-ray peak.

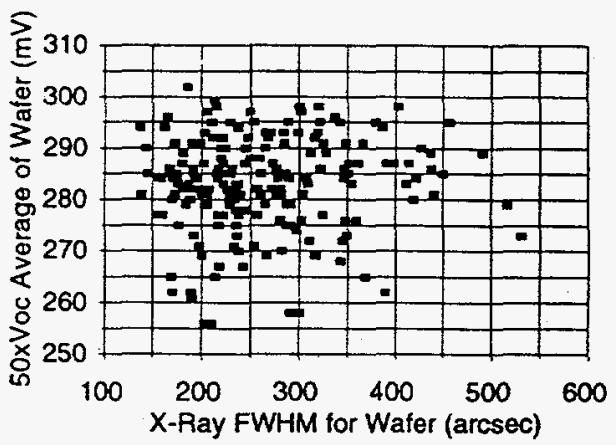

Fig. 3 Lack of correlation between the cell Voc and the FWHM of the material $X$-ray diffractometry peak.

\section{HISTOGRAMS}

Histograms of the Voc and FF data for the 2500 cells averaged in Table 2 are shown in Figures 4 and 5 , respectively. The data is slightly complicated since what is displayed is the average for all the cells on a wafer, with the majority of wafers being three-inches in diameter with twenty-four cells per wafer, with a significant number of twoinch wafers which had twelve cells per wafer included. 
One advantage of GaSb cells is that they have no epitaxial growth costs, since GaSb cells use PN junctions formed by dopant diffusion into GaSb wafers. However, GaSb is currently available only in 2-inch diameter wafers, while the 3-inch diameter InP wafers used for InGaAs cells have twice the area, resulting in twice as many InGaAs cells per processed wafer. InP wafers are available from several competitive vendors due to communications industry need for $1.5 \mu \mathrm{m}$ detectors and lasers, while GaSb wafer development is limited by the smaller GaSb TPV market.

Finally, a good optical filter [4] or reflector [5] is crucial for all cell types. Even for the InGaAs cell, $65 \%$ of the total $1200^{\circ} \mathrm{C}$ blackbody energy is from photons too low in energy to create electron-hole pairs in the cell. These photons would be wasted heating the cell if the filter did not reflect these photons back to the heat source. Less demanding, easier-to-realize, filters may be possible with the lower bandgap $0.55 \mathrm{eV}$ InGaAs since this cell uses more of the blackbody spectrum. In contrast, higher bandgap cells may need a more complex filter to reflect over a wider band.

\section{FABRICATION OUTLINE}

The material used for the $0.55 \mathrm{eV}$ cells was epitaxially grown on InP wafers in a commercial Spire $100 \mathrm{~S}$ metal organic chemical vapor deposition (MOCVD) reactor [6]. The epilayer structure (Table 1) was a fairly standard $\mathrm{N}$-on-P design except for proprietary composition, higher bandgap, back surface field and window layers used to minimize the recombination velocity at the back and front cell interfaces. Cell layers were grown lattice-mismatched to the supporting indium phosphide (InP) P-type substrate wafer. A conventional multistep in $G_{x} a_{1-x}$ As grading layer was used between the wafer and the cell to reduce dislocation defects. In a comparative test, this grading layer increased the observed open-circuit photovoltage by about $100 \%$ (from 150 to $300 \mathrm{mV}$ ) from a control test structure which had a simple in GaAs buffer layer instead of the grade.

Table 1 Epilayer Structure of 0.55 eV Cell

\begin{tabular}{|c|}
\hline - $200 \AA N_{++}$higher bandgap window \\
\hline - 2500 A N+ $\ln (72 \%) G a(28 \%)$ As emitter \\
\hline $3 \mu \mathrm{m}$ P. $\ln (72 \%) \mathrm{Ga}(28 \%)$ As base \\
\hline $5000 \AA P+$ higher bandgap back surface field \\
\hline $\begin{array}{c}\sim 4 \mu \mathrm{m} \ln (\mathrm{x}) \mathrm{Ga}(1-\mathrm{x}) \text { As step grading layer } \\
\mathrm{P}+\ln (72 \%) \mathrm{Ga}(28 \%) \mathrm{As} \\
\text { to } \\
\mathrm{P}+\ln (53 \%) \mathrm{Ga}(47 \%) \mathrm{As}\end{array}$ \\
\hline$-5000 \AA P+\ln P$ buffer layer \\
\hline-25 mil $P+\ln P$ wafer \\
\hline
\end{tabular}

Standard back contacts, front grid metal, and wet etching process steps were used to fabricate cells. Final cells were $1 \mathrm{~cm}$ by $1 \mathrm{~cm}$ in size with a shadow loss of about $10 \%$ for the busbar and $10 \%$ for the front contact gridlines.

\section{ILLUMINATED I-V DATA}

When the cells were illuminated to get an average 1.2 $\mathrm{Acm}^{2}$ short-circuit current density (Jsc), an average open-circuit photovoltage ( $\mathrm{Voc}$ ) of $283 \mathrm{mV}$ (best cell $307 \mathrm{mV}$ ) and average fill factor (FF) of $60 \%$ (best cell $67 \%$ ) resulted. The Voc, Jsc, and FF shown in Table 2 represent the average of over 2500 cell measurements. This $1.2 \mathrm{Acm}^{2}$ test current is not the maximum current (up to $5 \mathrm{Acm}^{2}$ could be used, with some fill factor degradation due to ohmic loss).

Table 2 Average (Standard Deviation) Data from 2500 in aaAs $0.55 \mathrm{eV}$ Cells (50X AMO)

\begin{tabular}{|c|c|c|c|c|c|}
\hline $\begin{array}{c}\text { Indium } \\
\%\end{array}$ & $\begin{array}{c}\text { Voc } \\
\mathrm{mV}\end{array}$ & $\begin{array}{c}\text { Voc/Eg } \\
\%\end{array}$ & $\begin{array}{c}\text { FWHM } \\
\text { arcsec }\end{array}$ & $\begin{array}{c}\text { Jsc } \\
{\mathrm{A} / \mathrm{cm}^{2}}^{2}\end{array}$ & $\begin{array}{c}\mathrm{FF} \\
\%\end{array}$ \\
\hline $\begin{array}{c}71.6 \\
(0.7)\end{array}$ & $\begin{array}{c}283 \\
(9)\end{array}$ & $\begin{array}{c}51 \\
(2)\end{array}$ & $\begin{array}{c}262 \\
(79)\end{array}$ & $\begin{array}{c}1.2 \\
(0.1)\end{array}$ & $\begin{array}{c}60 \\
(3)\end{array}$ \\
\hline
\end{tabular}

Table 2 data were measured under 50 sun air mass zero (AMO) "white-light" illumination. AMO light was used since it is well-defined and powerful sources are readily available. This data are directly applicable for determining Voc and FF for TPV applications if the heat source used in the TPV system generates the same photocurrent from the TPV cell as listed in Table 2. The rated Voc (283 mV) and FF $(60 \%)$ will be obtained whether the spectral content of the illumination is predominantly short (AMO) or long (e.g., a $1200^{\circ} \mathrm{C}$ blackbody) as long as the incident light drives the cell to $1.2 \mathrm{Acm}^{2}$, since the dark current (which affects the Voc) and the series resistance (which affects the FF) are spectrum-independent.

The data in Table 2 can be extended to other photocurrent levels since the $V o c$ at these higher illuminations was observed to be approximately diffusiondark-current limited with an ideality factor close to unity. If, for example, a TPV system designer expects to supply enough illumination so that the Jsc in Table 2 is tripled to 3.6 $\mathrm{A} / \mathrm{cm}^{2}$, the photovoltage can be roughly estimated to be $26 \mathrm{mV}^{*} \log (3)$ or $29 \mathrm{mV}$ higher than the value in Table 2 . The fill factor can be taken to be roughly constant for currents from about 0.5 to $4 \mathrm{~A} / \mathrm{cm}^{2}$. This procedure for estimates only works for photocurrents in this restricted range. For lower photocurrents, the procedure is invalid due to a biasvarying ideality factor much greater than unity. For higher photocurrents, the procedure breaks down because the fill factor can no longer be considered constant due to the higher $I^{2} R$ ohmic power loss. 


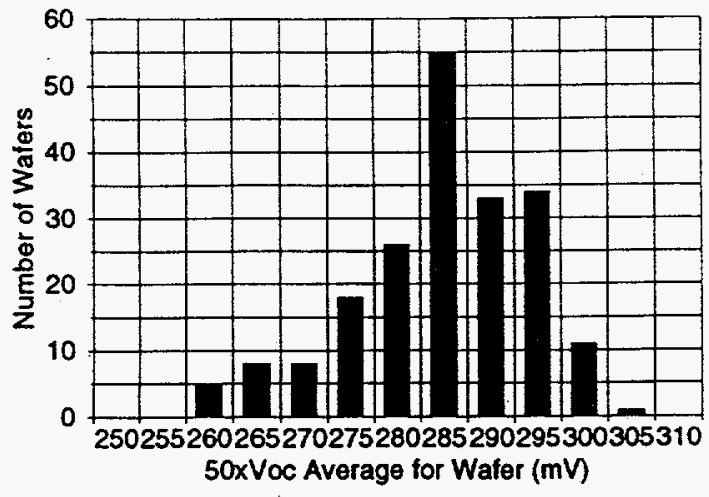

Fig. 4 Histogram of the open-circuit voltage of $25000.55 \mathrm{eV}$ In GaAs cells (see text).

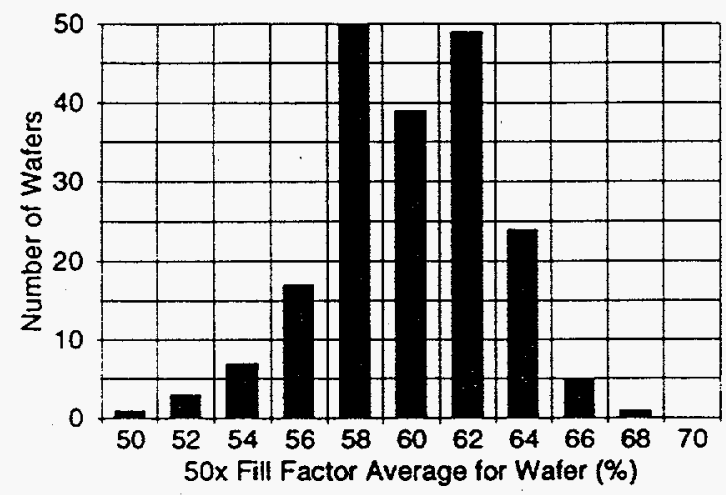

Fig. 5 Histogram of the fill-factor of $25000.55 \mathrm{eV}$ InGaAs cells (see text).

\section{SUMMARY}

In this paper, we presented some basic information on the average performance (based on 2500 cell measurements) of $0.55 \mathrm{eV}$ InGaAs thermophotovoltaic (TPV) cells that a TPV system designer would need to know. A typical quantum efficiency is presented (Figure 2), so that the photocurrent can be estimated if the heat source spectral density is known. Table 2 gives the typical average open-circuit photovoltage and fill factor that could be expected, and methods of extending this data to cover expected photocurrents in the 0.5 to $4 \mathrm{~A}_{\mathrm{cm}} \mathrm{cm}^{2}$ range is discussed. With these three parameters, the cell electrical output is predictable. Additional model data [7], including dark current and series resistance, are available for similar cells. Overall yields for these $0.55 \mathrm{eV}$ InGaAs cells $(-70 \%$ for $2500 \mathrm{~cm}^{2}$ of cells) were lower than that reported for about one-tenth the number of $0.6 \mathrm{eV}$ InGaAs cells [8]. In our process, most yield loss occurred when the fragile inP wafers were sawed into cells. We are currently improving the sawing technique and investigating other methods for separating cells.

\section{References:}

A. Schock, M. Mukunda, C. Or and G. Summers, "Analysis, Optimization, and Assessment of Radioisotope Thermophotovoltaic System Design for an Illustrative Space Mission," 1st NREL TPV Conf., AIP Conf. Proc. 321, 1994, pp. 331-356.

K.W. Stone, D.L. Chubb, D.M. Wilt, and M.W. Wanlass, "Testing and Modeling of a Solar Thermophotovoltaic Power System," 2nd NREL TPV Conf., AIP Conf. Proc. 358, 1995, pp. 199209.

[3] L.M. Fraas, H.H. Xiang, S. Hui, L. Ferguson, J. Samaras, R. Ballantyne, M. Seal, and E. West, "Development of a Small Air Cooled 'Midnight Sun' TPV Electric Generator," 2nd NREL TPV Conf., AIP Conf. Proc. 358, 1995, pp. 128-133.

[4] P.F. Baldassaro, E.J. Brown, D.M. Depoy, B.C. Campbell, and J.R. Parrington, "Experimental Assessment of Low Temperature Voltaic Energy Conversion," 1st NREL TPV Conf., AIP Conf. Proc. 321, 1994, pp. 29-43.

[5] G.W. Charache, D.M. DePoy, P.F. Baldassaro, and B.C. Campbell, "Thermophotovoltaic Devices Utilizing a Back Surface Reflector for Spectral Control," 2nd NREL TPV Conf., AIP Conf. Proc. 358, 1995, pp. 339-350.

[6] S. Wojtczuk, E. Gagnon, L. Geoffroy, and T. Parodos, "In(x)Ga(1-x)As Thermophotovoltaic Cell Performance versus Bandgap," 1st NREL TPV Conf., AIP Cont. Proc. 321, 1994, pp. 177-187.

[7] S. Wojtczuk, "InGaAs TPV Experiment-based Performance Models," 2nd NREL TPV Conf., AIP Conf. Proc. 358, 1995, pp. 387-393.

[8] P. Sharps, M. Timmons, R. Venkatasubramanian, J.S. Hills, B. O'Quinn, J.A. Hutchby, P.A. lles, and C.L. Chu, "Thermal Photovoltaic Cells," 1st NREL TPV Conf., AIP Conf. Proc. 321, 1994, pp. 194201. 


\title{
Production Data on $0.55 \mathrm{eV}$ InGaAs Thermophotovoltaic Cells
}

\author{
S. Wojtczuk and P. Colter
}

\author{
Spire Corporation, Bedford, MA
}

G. Charache and B. Campbell

Lockheed Martin, Inc. Schenectady, NY

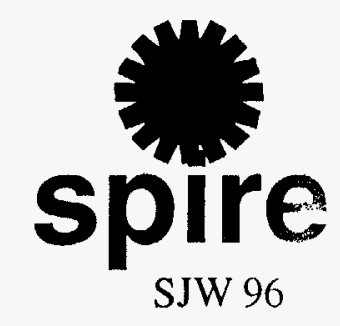


1200C Power Spectrum $\left(W / \mu \mathrm{m} / \mathrm{cm}^{2}\right)$ \&
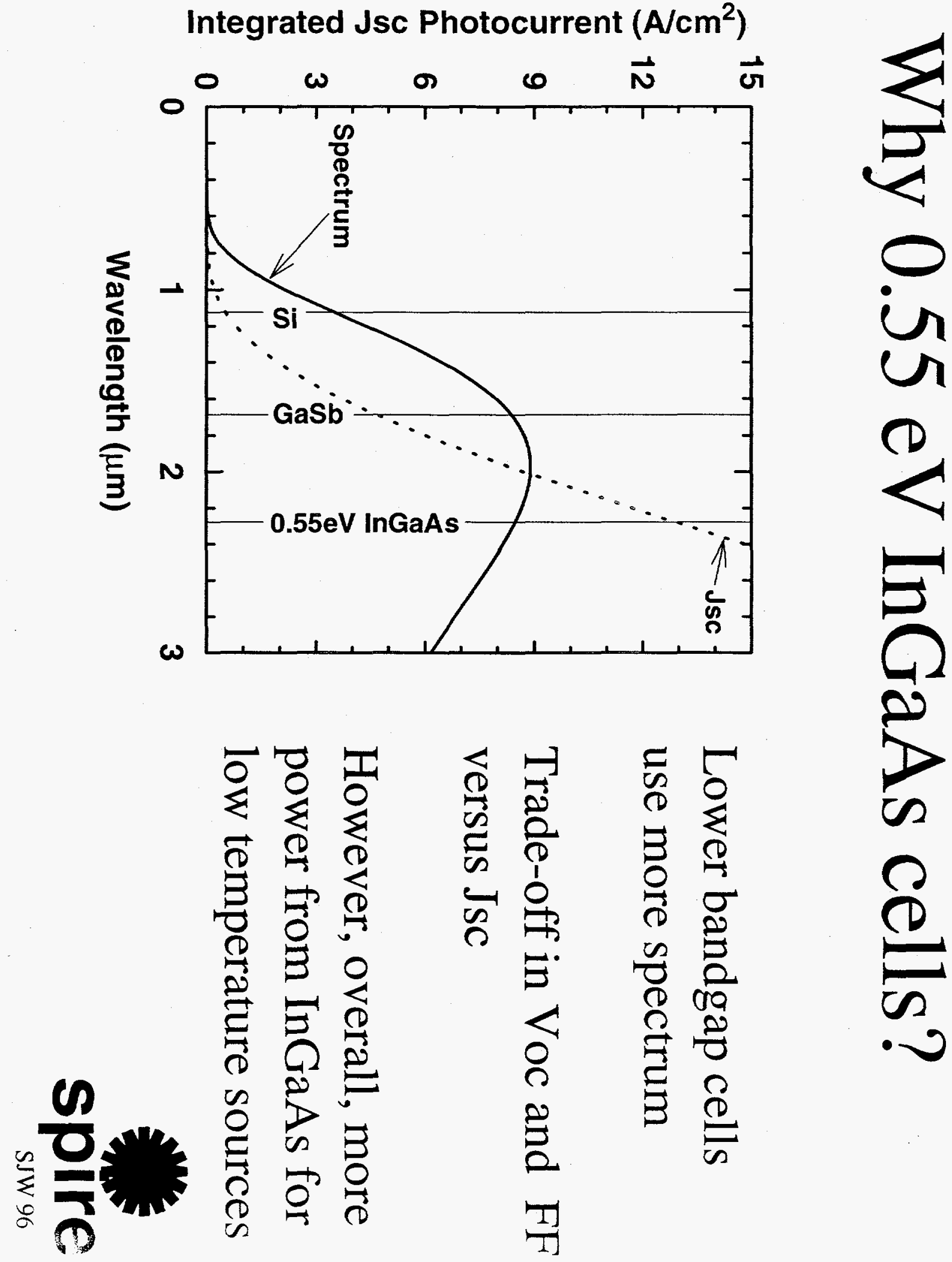

D

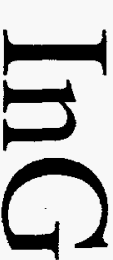

$D_{\infty}^{0}$

2

(D

$+$

$C 2$

$\rightarrow$ 


\section{Epilayer Structure of $0.55 \mathrm{eV}$ Cell}

\begin{tabular}{|c|}
\hline$\sim 0.02 \mathrm{um} \mathrm{N}++$ higher bandgap window \\
\hline$\sim 0.25 \mathrm{um} \mathrm{N}+\mathrm{In}(72 \%) \mathrm{Ga}(28 \%)$ As emitter \\
\hline$\sim 3 \mathrm{um} \mathrm{P}-\mathrm{In}(72 \%) \mathrm{Ga}(28 \%)$ As base \\
\hline$\sim 0.5 \mathrm{um} \mathrm{P}+$ higher bandgap back surface field \\
\hline$\sim 4 \mathrm{um} \mathrm{P}+$ step grading layer \\
$\mathrm{In}(72 \%) \mathrm{Ga}(28 \%) \mathrm{As}$ to \\
$\mathrm{In}(53 \%) \mathrm{Ga}(47 \%) \mathrm{As}$ \\
\hline$\sim 0.5 \mathrm{um} \mathrm{P}+\mathrm{InP}$ buffer layer \\
\hline$\sim 25 \mathrm{mil} \mathrm{P}+\mathrm{InP}$ wafer \\
\hline
\end{tabular}



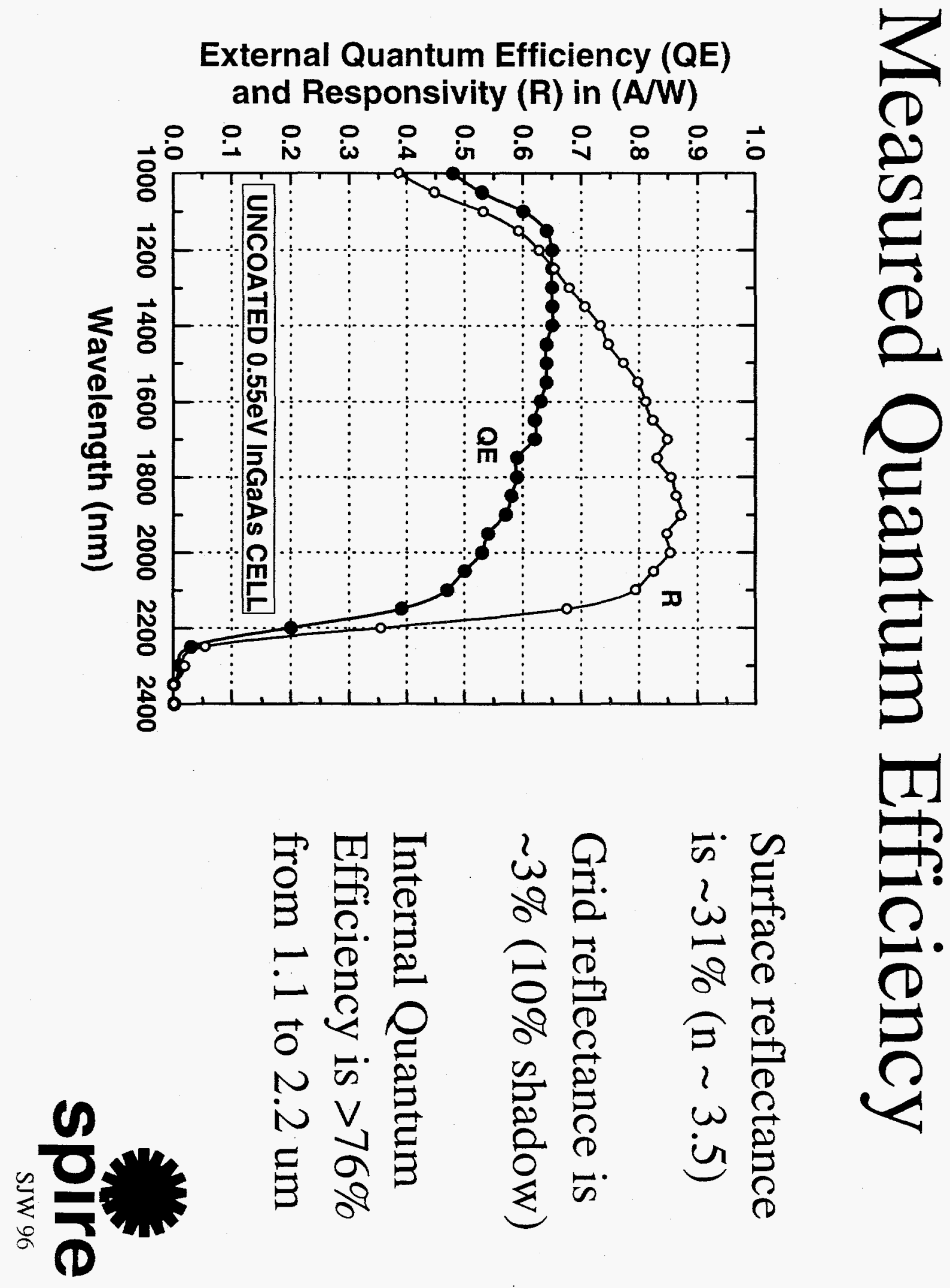

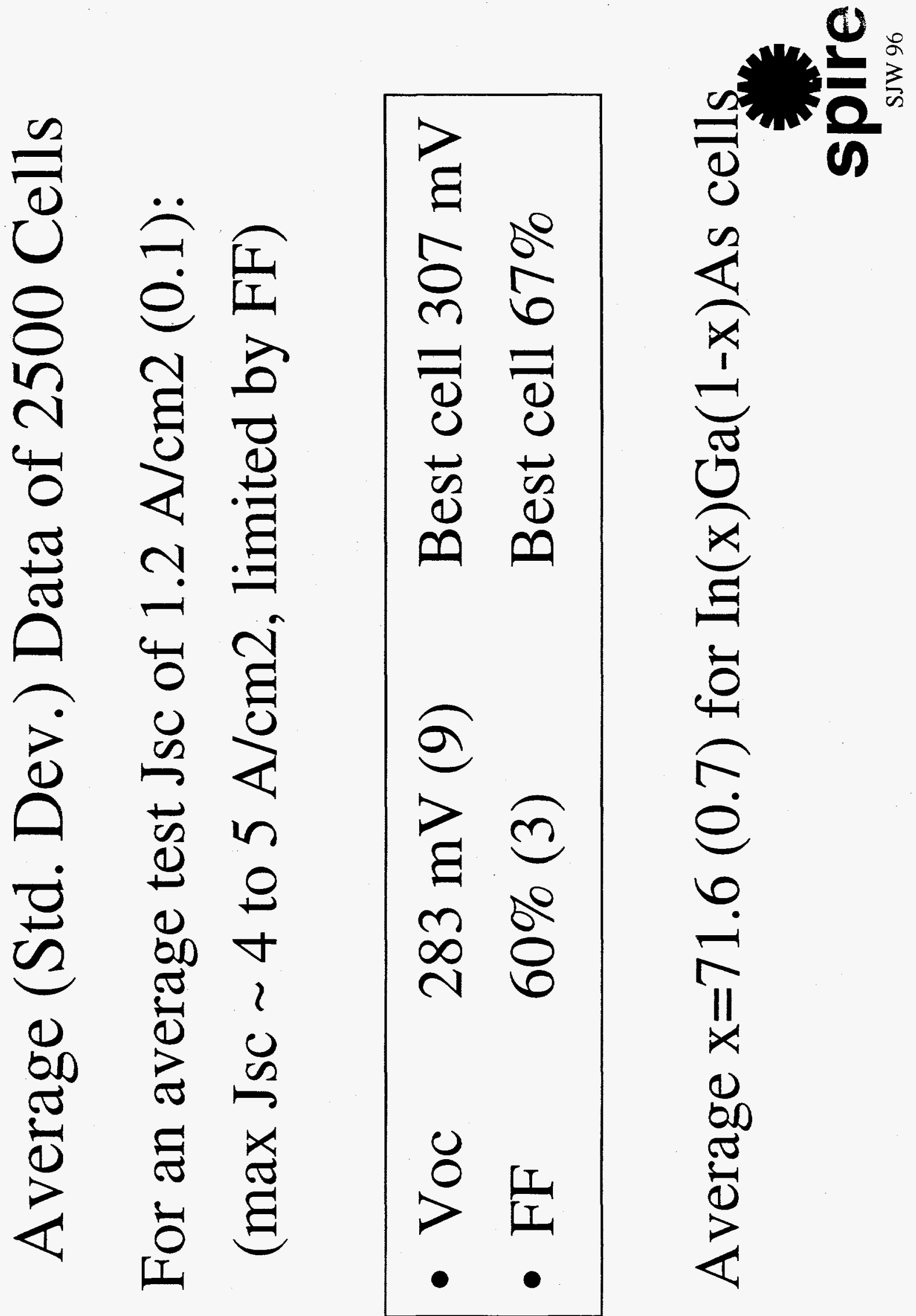

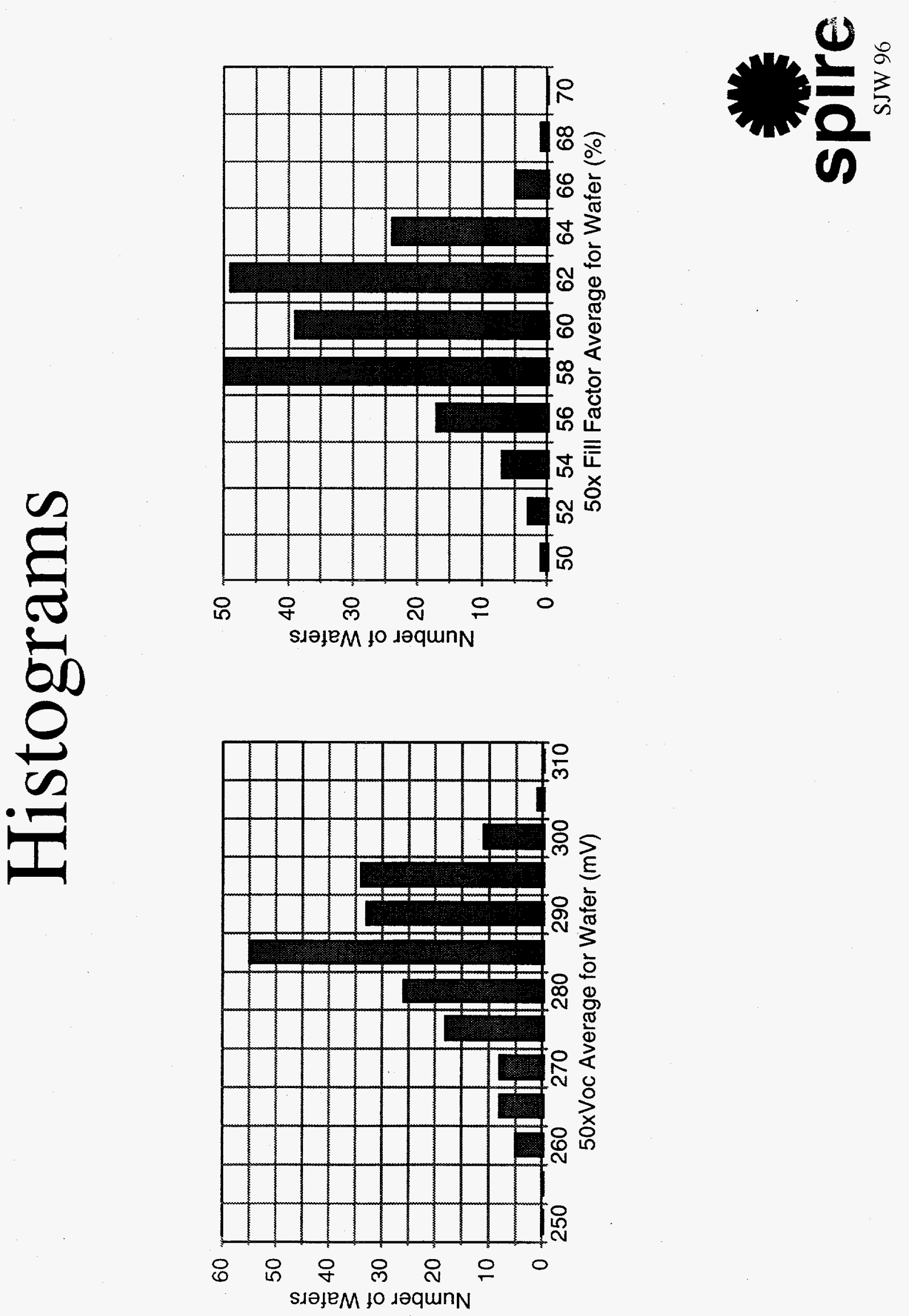


\section{Summary}

- We have presented data that should enable a TPV system designer to predict output power if the heat source spectral density is known

- Estimation procedure:

- Integrate QE with design spectrum to get Jsc

- ratio design Jsc to test Jsc to correct test Voc

- assume constant FF (within 10\% 0.4-4A/cm2)

- Avg qVoc $(283 \mathrm{mV})$ to $\mathrm{Eg}(550 \mathrm{meV})$ ratio of $51 \%$ is extremely good for lattice-mismatched cells 